has not gained from the breach. $2 \pi$ But where the defendant profited from a substitute contract over and above his expenses on both transactions, and the plaintiff suffered "out-of-pocket" losses, defendant should be liable for these losses to the extent of his profit from the substitute contract. ${ }^{28}$ Considerations of "fairness and justice" would be better served by such a solution than by the vague tests of liability and the "all-or-nothing" rule of damages the court applied in the Jackson case. 29

\title{
JOINDER OF THE GOVERNMENT UNDER THE FEDERAL TORT CLAIMS ACT*
}

WITH the avowed purpose of placing Government tort liability on a par with private liability, Congress relaxed sovereign immunity by enacting the Federal Tort Claims Act. ${ }^{1}$ Complete parity has not been achieved, however, in administration of the Act. Where private tortfeasors are involved, federal courts universally permit plaintiffs to join several defendants.? Similarly, where local substantive law allows it, original defendants may implead private joint

tract while plaintiff has lost his anticipated profits. But since the breach occurred through no fault of defendant's and since neither party has sustained "out-of-pocket" losses, it is felt that courts should leave the parties where it finds them instead of attempting nice calculations as to their relative gains.

27. An alternative solution would be to have the parties divide their total economic loss. A drawback to this scheme, however, is that an injured party who is ignorant of the other's ultimate economic position might hesitate to bring a suit for fear that the latter's loss might have exceeded his own.

28. The ordinary reasons for protecting the plaintiff's expectation interest, see Fuller \& Perdue, supra note 23 , at $59-62$, do not apply here, since the alternative to partial recovery, in cases of excusable breach, is no recovery.

29. Another possible approach to the problem is legislative rather than judicial. Upon the outbreak of hostilities, Congress might establish a system of government-operated, non-profit, contract insurance, covering the risk of wartime impossibility. Such a solution would achieve a wide distribution of the burdens of impossibility among all those paying premiums, protect private parties from severe losses, and avoid litigation in these cases.

* Howey v. Yellow Cab Co., 181 F.2d 967 (3rd Cir. 1950); Capital Transit Co. v. United States, 183 F.2d 825 (D.C. Cir. 1950).

1. 60 STAT. $\$ 42$ (1946), as amended, 28 U.S.C. $\$ \S 1291,1346,1402,1504,2110,2401$, $2402,2411,2412,2671-80$ (1948). The provisions of the Tort Claims Act remained substantially unchanged by the revision of the Judicial Code, effective September 1, 1948, 62 Stat. 869 (1948), although all sections were renumbered. See Table 1, an addendum to revised 28 U.S.C.

2. Joinder is allowed subject to Rule 20(a) FED. R. Crv. P. See 3 AfoonE's Ferzzar. Practice $\$ 20.06$ (2d ed. 1948). 
tortfeasors to compel contribution toward payment of damages. ${ }^{3}$ Thus, the evils of multiple suits are avoided. But whether the FTCA permits joinder of the Government in either circumstance remains undetermined. The Act is completely silent ${ }^{4}$ and the courts are divided.5

Howey v. Yellow Cab Co. ${ }^{6}$ and Capital Transit Co. v. United States, recent decisions of the United States Courts of Appeals for the Third Circuit and District of Columbia respectively, illustrate this split. The facts in the two cases were essentially the same. ${ }^{8}$ In both cases the private defendant attempted to implead the Government for contribution under the FTCA. Contribution was a substantive right, ${ }^{\circ}$ and joinder would have been allowed had the joint tortfeasors been private parties. The Court of Appeals for the Third Circuit

3. FED. R. CIv. P. 14(a). Contribution is not uncommon. While it was unknown to the common law until the case of Merryweather v. Nixan, 8 T.R. 186 (K.B. 1799), it now exists under statute in approximately twenty American jurisdictions and in another dozen under judicial decision. See Gottlieb, Some Aspects of Contribution and Indemnity in Tort Actions Against the United States, 9 FED. B.J. 391 (1948) and Leflar, Contribution and Indennity Between Tortfeasors, 81 U. of PA. L. Rev. 130 (1932). See also note 24 infra.

In states which do not allow contribution, joinder of private joint tortfeasors in the federal courts for the purpose of enforcing contribution is, of course, improper under Erie R. Co. v. Tompkins, 304 U.S. 64 (1938). 3 Moore's Federal Practice $\$ 14.03$ (2d ed. 1948). Generally, secondarily liable defendants may join private defendants primarily liable in order to secure indemnity. But since the right to indemnity stems from a contractual relationship, e.g., master-servant, Government liability for indemnity may depend on the Tucker Act rather than the FTCA. Gottlieb supra; Leflar supra.

4. See note 14 infra.

5. Joinder has been denied in the following cases: Capital Transit Co. v. United States, 183 F.2d 825 (D.C. Cir. 1950) ; Sappington v. Barrett, 182 F.2d 102 (D.C. Cir. 1950) ; Prechtl v. United States, 84 F. Supp. 889 (W.D. N.Y. 1949) ; Donovan v. McKenna, 80 F. Supp. 690 (D. Mass. 1948) ; Uarte v. United States, 7 F.R.D. 705 (S.D. Calif. 1948) ; Drummond v. United States, 78 F. Supp. 730 (E.D. Va. 1948).

Joinder has been permitted in the following cases: Howey v. Yellow Cab Co., $181 \mathrm{~F} .2 d$ 967 (3rd Cir. 1950) ; Englehardt v. United States, 69 F. Supp. 451 (D. Md. 1947) ; Maryland v. Manor Real Estate \& Trust Co., 83 F. Supp. 91 (D. Md. 1949); Newsum v. Pennsy1vania R. Co., 79 F. Supp. 225 (S.D. N.Y. 1948) (United States joined by individual defendant who sought indemnity); Rivers v. Bauer, 79 F. Supp. 403 (E.D. Pa. 1948) (joinder question not argued) ; Bullock v. United States, 72 F. Supp. 445 (D. N.J. 1947).

An entirely different problem is raised where joinder is at the instance of the government, since no question of sovereign immunity is involved in such cases. See notes 14 and 15 infra. 3 Moore's Federal Practice $\S 14.29$ (2d ed. 1948). The question may be moot since the Justice Department has been reluctant to ask for contribution or indemnity. Collet, Federal Tort Clains Act, 8 F.R.D. 1 (1948).

6. 181 F.2d 967 (3rd Cir. 1950)

7. 183 F.2d 825 (D.C. Cir. 1950).

8. The Capital Transit court made no attempt to distinguish the Howcy case, stating, "We are constrained to disagree with the learned judges of the Third Circuit." 183 F.ad $825,827$.

9. Knell v. Feltman, 174 F.2d 662 (D.C. Cir. 1949) (Capital Transit jurisdiction), noted in 48 Mrcr. L. Rev. 879 (1950) ; Kravas v. Great Atlantic \& Pacific Tea Co., 28 F. Supp. 66 (W.D. Pa. 1939) (Howey jurisdiction). 
allowed joinder of the Government in Howey, but the Court of Appeals for the District of Columbia denied it in Capital Transit.

The Capital Transit court relied primarily on two grounds: the legislative history of the FTCA and an analogy to the Tucker Act, which permits contract suits against the United States, and is silent on the joinder question. In its historical argument the court noted that the congressional committee report on the final draft of the Tort Claims Act made no mention of joinder. ${ }^{10}$ The court resorted, however, to a report on an earlier version which recommended prohibition of joinder. ${ }^{11}$ In stressing this report, the court ignored an earlier bill which favored joinder. ${ }^{12}$

The Capital.Transit court's analogy to the Tucker Act ${ }^{13}$ relied heavily on a Supreme Court decision denying joinder under that Act on the theory that surrenders of sovereign immunity should be strictly construed. ${ }^{14}$ Proceeding from this ruling, the Capital Transit court found no difficulty denying joinder under the Tort Claims Act.

Both the historical and the analogical arguments were forcefully countered in the Howey opinion. Recalling that congressional committee reports had shifted on the question of joinder, the Howcy court regarded the legislative history as inconclusive. In answer to the Tucker Act analogy the Honcey court pointed to the recent trend away from strict construction of waivers of

10. Sen. Rep. No. 1400, 79th Cong., 2d Sess. 29 et seq. (1946).

11. H.R. REP. No. 1287, 79th Cong., 1st Sess. 5 (1945) contained the following language: "The bill therefore does not permit any person to be joined as a defendant with the United States and does not lift the immunity of the United States from tort actions except as jurisdiction is specifically conferred upon the district courts by this bill."

12. SEN. 2690, 76th Cong., 1st Sess. §306 (1939) read: "If the damage, loss, injury" or death is caused under circumstances creating a legal liability on the part of some person other than an officer, agent, or employee of the Government or upon some corporation, state or political subdivision, to pay damages therefor, jointly with the United States, then, and in that event, the recovery against the United States shall be only for the pro rata share of the damages in proportion to the number of parties, so jointly or severally liable." Similar language may also be found in H.R. 6463, 77th Cong., 2d Sess. $\$ 403$ (1942).

13. 24 Stat. 505 (1887), 28 U.S.C. $\$ \$ 791,1331-46,1348,1350,1351,1353-57,1359,1397$, $1399,1402,1491-94,1496,1501,1503,2071,2072,2361,2401,2402,2411,2412,2501,2509-11$ (1948).

14. United States v. Sherwood, 312 U.S. 584 (1941). This case has been cited by all of the courts denying joinder under the FTCA. The direct argument almost always available to counter the strict construction theory is the maximum, expressio tunits cst cxclusio alterius. This is especially true where, as in the Tort Claims Act, a number of exceptions to Government liability are included, with joinder noticeably excluded. 28 U.S.C. $\$ 1402$ (b) , 2401, 2402, 2674, $26 \$ 0$ (1948). See also note 15 infra.

Another weakness in the Tucker Act analogy lies in the fact that that Act was passed in 1887, long before the Federal Rules of Civil Procedure, with their liberal joinder provisions, were drafted.

And the policy of the Sherw'ood decision has been criticized: "the Court's approach in the Sherwood opinion tends to make the matter of sovereign-immunity a fetish, while the tendency should be in the other direction-toward the complete removal of the sovercignimmunity obstacle to suit" 3 MIOORE's Federal Practice \$20.07 [3] (2d ed. 1948). 
sovereign immunity. Indeed, the strict construction theory, upon which joinder under the Tucker Act was denied, was recently rejected by the Supreme Court itself in a decision permitting insurer-subrogees to ste the Government under the Tort Claims Act. ${ }^{15}$

Howey further undercut the Tucker Act analogy with closer analogies to the Suits in Admiralty Act ${ }^{10}$ and the Public Vessels Act. ${ }^{17}$ Under these acts, which deprive the United States of immunity from maritime tort liability, but, like the FTCA, ${ }^{18}$ make no mention of joinder, the government can unquestionably be joined. ${ }^{10}$ Moreover, these acts postdate the Tucker Act, and sound in tort rather than contract.

The Howey court had a strong affirmative basis as well. It recognized the positive expression of congressional intent in the Tort Claims Act itself. It looked to the purpose of the Act as expressed in the provision that " $\mathrm{t}$ ] United States shall be liable . . . in the same manner and to the same extent as a private individual under like circumstances [;]"20 and in the section conferring jurisdiction for tort claims against the Government "under circumstances where the United States, if a private person, would be liable to the claimant in accordance with the law of the place where the act or omission

15. United States v. Aetna Surety Co., 338 U.S. 366 (1949). The following langualge of the Supreme Court in rejecting the strict construction argument is particularly noteworthy: "In argument before a number of District Courts and Courts of Appeals, the Government relied upon the doctrine that statutes waiving sovereign immunity must be strictly construed. We think that the congressional attitude in passing the Tort Claims Act is more accurately reflected by Judge Cardozo's statement in Anderson v. Hayes Construction Co., 243 N.Y. 140, 147, 153 N.E. 28, 29-30: 'The exception of the sovereign involves hardship enough where consent has been withheld. We are not to add to its rigor by refinement of construction where consent has been announced." Id. at 383. Earlier evidence of the trend away from sovereign immunity is United States v. Shaw, 309 U.S. 495, 501 (1940): "A sense of justice has brought a progressive relaxation by legislative enactments of the rigor of the immunity rule. As representative governments attempt to ameliorate inequalities as necessities will permit, prerogatives of the government yield to the needs of the citizen."

16. 41 Stat. 525 (1920), 46 U.S.C. $\$ 741$ et seq. (1944).

17. 43 Stat. 1112 (1925), 46 U.S.C. \$ 781 et seq. (1944).

18. See note 14 supra. The language of these statutes, moreover, is strikingly similar to the FTCA in calling for parity of Federal liability with private liability. Compare 41 StaT. 526 (1920), 46 U.S.C. \& 743 (1944), and 43 Stat. 1112 (1925), 46 U.S.C. \$ 782 (1944) with the text accompanying notes 20 and 21 infra.

19. Hust v. Moore-McCormack Lines, 328 U.S. 707 (1946) (Suits in Admiralty Act); The Cotati, 2 F.2d 394 (S.D. N.Y. 1923) (Suits in Admiralty Act); Olavarria \& Co. v. United States, 56 F. Supp. 758 (S.D. Ala. 1944) (Suits in Admiralty Act, with dicta that joinder permissible under Public Vessels Act); Porello v. United States, 153 F. 2d 605 (2d Cir. 1946), aff'd in part and rev'd in part on other grounds sub nom Americall Stcoddores v. Porello, 330 U.S. 446 (1947) (Public Vessels Act).

20. 28 U.S.C. $\$ 2674$ (1948). The Supreme Court clearly recognized this purpose in United States v. Aetna Surety Co., 338 U.S. 366, 380 (1949) when it referred to the "broad sweep of [the Act's] language assuming the liability of a private person." 
occurred."21 In view of this purpose, Government joinder should never be denied a plaintiff. It should always be granted a defendant seeking to enforce a substantive right to contribution. ${ }^{22}$

The desirability of avoiding multiple suits is the most persuasive reason for adopting this rule. Laudable progress in the reduction of repetitious litigation has been achieved under the Federal Rules of Civil Procedure. In permitting a plaintiff to join private defendants, ${ }^{23}$ the Rules save him the trouble of choosing from among several potential defendants the one most likely to be both liable and well-heeled, a choice coupled with the possibility of successive lawsuits until an enforceable judgment is obtained. And in jurisdictions permitting contribution, the Rules save the defendant extra litigation by permitting him to join other tortfeasors. ${ }^{24}$ Denial of joinder under the Tort Claims Act is an unjustifiable retrogression from the spirit of the Rules. ${ }^{25}$

Joinder has been opposed, however, on the ground that it would require the Court of Claims, which shares review of FTCA suits with courts of appeals, 9 to appraise jury verdicts and to mediate private disputes. Such review, it is argued, is foreign to the Court of Claims' nature. This argument assumes that the Court of Claims would have jurisdiction to review issues between private parties. But section 1504 limits Court of Claims jurisdiction to " . .

21. 28 U.S.C. $\$ 1346(b)$ (1948).

22. Whether contribution may be enforced against the Government under the Act, should, of course, depend upon local law. One federal district judge has concisely stated the proper test as follows: "Local law will determine as between the Government and a joint tortfeasor, issues of pro rata liability and rights of contribution." Hulen, Suits or Tort Clains Against the United States, 7 F.R.D. 689, 700 (1948).

In some states joinder is a prerequisite to contribution, a further reason for permitting joinder under the Act. Leflar, supra note 3, at 144 n.66.

23. FED. R. CIV. P. 20(a).

24. FED. R. CTv. P. 14(a). The doctrine of contribution has been criticized as a poor means of distributing losses. James, Contribution Among Joint Torlfeasors; A Progmatic Criticism, 54 HARv. L. REv. 1156 (1941). But regardless of its wisdom, it holds sway in approximately thirty jurisdictions. See note 3 stpra.

25. The English equivalent to our Tort Claims Act, the Crown Proceedings Act, avoids any doubt as to joinder by providing for proceedings "in accordance with rules of court and not otherwise." Crown Proceedings Act of 1947, 10 \& 11 Geo. 6, c. 44, §13. A simple amendment to the FTCA in similar language would expeditiously resolve the joinder question in this country. For a comparison of the. Tort Claims Act and the Crown Proceedings Act, see Street, Tort Liability of the Stafe: The Federal Tort Claims Act and the Crown Proceedings Act, 47 Mircr. L. Rev. 341 (1948).

Originally the Tort Claims Act provided: "In actions under this subchapter, the forms of process, writs, pleadings, and motions, and the practice and procedure, shall be in accordance with the rules promulgated by the Supreme Court. . . ." 28 U.S.C. \$932 (1946). When Title 28 of U.S.C. was revised and codified, this section was deleted as sirplusage "since other provisions of the title provide that tort claims shall be asserted in civil actions and that the Rules of Civil Procedure promulgated by the Supreme Court shall apply to all civil actions." Sen. Rep. No. 1559, 80th Cong., 2d Sess. 12 (1948). See also Comment, The Federal Tort Clains Act, 56 Yale L.J. 534, 554 (1947).

26. 28 U.S.C. $\$ \$ 1291,1504,2110$ (1948). 
civil actions based on tort claims brought under [the Act.]"27 Suits against private defendants, though joined with the Government, are in no sense actions brought under the Act. Therefore if section 1504 were construed to mean only suits based wholly on the Act, ${ }^{28}$ the Court of Claims would have no jurisdiction of an action in which private persons and the Government are sued jointly. Instead, all appeals in joinder cases would go to the courts of appeals. Yet such an interpretation would not mean a substantial decrease in the Court of Claims' jurisdiction, for review by that court is already contingent upon consent of all appellees. ${ }^{29}$

Since the Tort Claims Act denies a jury trial in suits against the Government, ${ }^{30}$ joinder might be further construed to interfere with the constitutional right of jury trial. But the Federal Rules are flexible enough to allow trial of Government issues to the court and private issues to the jurys ${ }^{31}$ And while practical difficulties may be imagined in cases where the judge and jury disagree, ${ }^{32}$ such difficulties would be no more serious than those which might arise in separate actions against the Government and its joint tortfeasor. Indeed, joinder would reduce the likelihood of conflicting decisions : both results can at least be based on the same evidence $;^{33}$ and the court, while it may disagree

27. "The Court of Claims shall have jurisdiction to review by appeal final judgments in the district courts in civil actions based on tort claims brought under section 1346(b) of this title. . . " 28 U.S.C. $\$ 1504$ (1948): Section 1346(b) provides for tort actions against the Government only.

The appellate jurisdiction of the courts of appeals similarly refers to claims brought under the Act. But courts of appeals, unlike the Court of Clains, are granted jurisdiction over the issues between private persons so long as the usual federal jurisdictional requirements arè met. 28 U.S.C. $\$ 1291$ (1948).

28. Cf. Bartram v. Town of Sharon, 71 Contr. 686, 43 Att. 143 (1899); Cogswell v. New York, N.H. \& H.R., 105 N.Y. 319, 11 N.E. 518 (1887).

29. 28 U.S.C. $\$ 1504$ (1948). In view of this requirement, and the fact that the Court of Claims sits only in Washington, D.C., it is unlikely that many FTCA cases will be taken to the Court of Claims. The presence of additional parties in a joinder case, of course, further decreases the likelihood of an appeal to that court.

If courts are unwilling to construe $\S 1504$ in the manner suggested, an alternative interpretation is available. It can reasonably be argued that even in a joinder case, $\$ 1504$ does not give the Court of Claims authority to review issues arising between private parties, but only those arising between a private plaintiff and the Government. This would permit separate appeals in joinder cases in the rare situation where all appellees agree to Court of Claims review. Separate appeals are permissible under the Federal Rules. FED. R. Crv. P. 74.

30. "Any action against the United States under section 1346 of this title shall be tried by the court without a jury." 28 U.S.C. $\$ 2402$ (1948).

31. FED. R. Civ. P. 38, 39. This procedure was followed without difficulty in Englehardt v. United States, 69 F. Supp. 451 (D. Md. 1947), one of the leading joinder cascs. See also Ring v. Spina, 166 F.2d 546 (2d Cir. 1948) and Elkins v. Nobel, 1 F.R.D. 357 (E.D. N.Y. 1940) for illustrations of the flexibility of this procedure.

32. See, e.g., The Capital Transit case; Comment, The Federal Tort Clains Act, 56 YALE L.J. 534, 555 (1947).

33. For realistic treatment of the question of trial of jury and non-jury issues and the 